\title{
「話すこと」の習熟
}

\section{Some Suggestions for a Better Oral Presentation}

\author{
吉 本 瑞 應*
}

奈良県立医科大学附属図書館

\section{はじめに}

「なぜ」という強い疑問をもち，「研究」を日常化する ことから，「研究する態度・姿勢」が身についてくる。そ うした生活実践の中から，よい「研究成果」が生まれる。 さらに，その成果を活字として，あるいは，大ぜいの人 前で「発表」する。常にみずからを, みずからの手で高 めていくほかに, 医学図書館員人材の育成は望み得ない という私自身の信念のもとに提言し，実施したのが今日 の「研究集会」「セミナ一」である。

第 7 回という，私にとってひとつの意味を持つセミ ナーを担当することになり，その成長，成果を自分でた しかめなければならない立場におかれたことが，この二 日間，私を終始参加者とともに釘付けにさせた。会場は 活気に満ち, 内容的にも充実した, 実り多い, 大きな成 果を得たことは，何よりもよろこばしいことである。

しかし，口頭で「発表する技術」は率直に言って，お 粗末である。切角の立派な研究内容も, 話すことの術・ 演出の効果如何で, 随分違ってくるのではないだろうか。 今後のセミナ一を，さらに秀れたものにさせる契機とも なればと筆をとることにした。

利用者の中には, 何となく虫の好かない顔, 態度が気 に喰わないと思う人がいるものであるが，同様に，好か れていない,嫌がられている館員も必ずいるものである。 利用者の要求するキーポイントを把握できなかった ク，図書館専門用語を使い過ぎたり，冷たい言葉使いや，

* Zuio YOSHIMOTO : Nara Medical University Lib-

rary, 840, Shijo-cho, kashihara City, Nara 634, Japan.

(昭和 55 年 11 月 1 日 受理)
俗ぽい表現を使ったり，高姿勢な態度などとろうものな らて゚っきりである。

利用者との言葉のやりとりは，図書館員にとって大き い意味を持つ。困書館の印象・評価, 信頼・親和感, す べて，このコミュニケーション スキールにかかってい るということをよく心得ておかねばならない。それは， 丁度医師が患者との問診でおこなうのと，同じ重要性を もつものである。

話し方，聞き方，質問の仕方，答之方，傾聴的態度， ゼスチャー, タイミング, テンポなどは, 当然身につけ ていなければならない,一つの専門的技術であると思う。

私の受けてきた教育をふり返ってみても，読み書きに 偏し，今日ほど「話すこと」を重視されていなかった。 外国語の学習では, 口の開き方, 舌の動かし方, アクセ ント, イントネーションのつけ方から, 話し方に至るま で, 一応教わる過程を通った。しかし，こと国語に関し ては, 全くそれらの訓練はなく, 自分の考えや, 自分の 主張を「話す」ことの指導も，また，人の話しをいかに して「聞く」かということの教育も，なかったことが不 思議に思うくらいである。

寺に生まれ䏍った私には，小さい頃から,，巧妙な話芸 に魅了されたことも少なくなかったが，これらは，すべ て家庭や環境から学んだ貴重な体験であったろうか。

人前で話す勇気の点では，また，どちらかと言えば, 形式ばらない「討議」の場での話し合いは, 第 1 回医学 図書館員セミナ一の頃とでは，問題にならないほど目 立った上達がみられる。しかし，大ぜいを相手に，あら たまっての発表となると「へたくそ」と言わざるをえな い。発表技術を身につけるための積極的な工夫が望まれ 
吉本：「話すこと」の習熟 239

ることを強調したい。

限られた時間内に，自分の研究成果をどうまとめて話 すか, どの部分を特に強調するか, 結論は, また演出効 果をも，あらかじめ考之た周到な準備と基礎的な訓練が 何よりも必要である。ただ，用意した原稿を早口で読み あげるのに終始している。あの調子なら，たとえ場数を 踏んだとしても，よい結果が生まれることを期待するこ ともむずかしいと思われる。

発表時間 1 人「15 分」（厳守）は, 実施要領にも示し, 本人にも通知して，よくよく了解されている筈である。 にもかかわらず，時間内に収められる人は少なく，5分 前の鈴で，あわてふためき，1分前の知らせで血相を変 之, 猛スピードで残りの原稿にしがみつきながら読み, 持ち時間なしでストップさせられる。なかには，司会者 のストップにも動じることなく読み続けよっとする人も いる。

研究発表では, 参加者一人一人に, 自分の研究成果の 内容を正確に伝え，理解してもらうことが主である。印 刷論文と違って, 話すのは一回限りである。しかも, 言 葉は瞬間的に消えてゆく。それでも，聞き手は聞き返す ことさえできない。したがって, 話しぶりも耳で聞いて, やさしい，わかりやすい話し言葉で，比較的短いセンテ ンスで話さなければならない。同じ語句を繰り返したり, 別の言葉で言いかえたりすることも当然必要になってく るのもこのためである。

話す速さは, 普通の会話で話す時よりもゆっくりめに 話し, 私の経験から, 平均 1 分間 200 字程度だろうか。 内容にもよるが, よく研究して原稿の量をきめることが 何よりも大切である。

原稿の内容を決める場合に，研究成果をどのようにま とめるか。また, それをどんな順序で出すか, 時間の割 り振りをも考えて，あらかじめよく練っておかねばなら ない。発表の言い出し方にも工夫したいものである。ま ず, 発表する動機, 理由を話し, これから自分の発表す る内容がどのような意味があるかについて，はっきり話 すことが参加者をひきつけるコツである。また，現在ま でのこのテーマに関しての研究を簡単に紹介することも 言い落してはならない。続いて，特に主張したいことを
客観的に強調し，しかも，それが正しい調査結果などに もとづいていること。また，自分とは反对の考えや意見 が適当でないことを，色んな角度から批判することを忘 れないで, 結論へと導くことが大切である。話しの終り には, 自分の考え・主張の要点をはっきり繰り返し, 決 められな時間内にきちんと結びたいものである。

今回, 発表の持ち時間は正味 15 分で, セミナ一当日に なっても変更しなかったが, 色んな都合でとっさに変え られることも起り得る。だから, 原稿の量もあらかじめ 規定時間の分のほかに, その時の事情により慌てず延し たり, 縮めたり, 臨機応変の処置がとうさにとれるよう な工夫を原稿に示しておくことが大切で，特に残り時間 一分の量は別に用意する位の周到さで，一にも二にもふ だんの準備が大切である。

原稿なしで，ほんの個条書き程度のメモを参考に，自 由自在に発表している人をみると, 何となくゆとりが感 じられ，聞く側にとっても，楽に聞けるものではあるが, 持ち時間を正確に使い，内容を言い落すことなく伝える ためには、しっかりした原稿を用意した方が賢明である。

原稿を見ると言っても，片時も目を離すことなく，指 で行を追いながら発表しているのは，見苦しい。時には， 一人一人に話しかけるようにして，参加者を見渡すくら いの余裕がほしいものである。参加者の同意を求めるの も注意を集中させるコツである。

発表の途中で，気まずさや，間もちに，咳ばらいをし たり，意味のない「アー」,「エー」などは，聞き苦しい もので慎しむようにしたいものである。

とくに, 大ぜいの前で話す時は, 言葉の終りが不明瞭 になり，聞きとりにくくなるものであるが注意したい。 かと言って, 最近の語尾を意識的に強く言い過ぎる風習 も，耳障りでいただけないものである。

実行委員を忙しくさせたのは, スピーカーのボリュー ムの調整である。ふだんの普通の声で, 自然な調子を崩 さないよう，どちらかと言えば, 低めの声で話せばよい ものを，怒鳴りに近い声で，なかには，呼吸音まで聞之 てくる人もいる。また, 逆に囁くように話し, 聴衆の眠 気をいやがうえにも誘うのも迷惑なはなしである。ス ピーカーから流れる自分の声を確かめながら, マイクロ フォンの感度を, マイクロフォンとの距離, 向きを自分 で調整するゆとりがほしいものである。 


\section{0 医学図書館 Vol. 27 No. 4, 1980}

動作，身振りや表情も，きびきびしているのは，何と なく気持がよいものである。何よりも，生き生きとした 活気が感じられしかも物柔らかな物腰は好感がもてる。 それも，自分の話す内容について，これは自分でなけれ ば話せないという，静かな自信がその根底になければな らない。平素から人の話しぶりをよく観察して，勉強を する習慣をつけておくことも大切である。

まったく本人は気がつかないものであるが，人には 色々な癖がある。頭をかいたり，話しながら貧乏ゆすり をしたり，手をポケットに入れたまま話したり，といっ た具合である。注意しなければならないことだと思う。

プログラムの作成に当っては，聞く側の注意をそらさ せないためにも, 少くとも 1 時間半を越えないところで, 休憩をとるよう配慮したが，聞き手の注意をそんなに長 く集中させ続けることは非常にむずかしい。したがって， 「間」のとり方を工夫し，参加者に考える時間を持たせ たり，印象を強めたりすることも必要である。力を入れ て話すところと，そうでないところと区別したり，言葉 に抑揚をつけ，単調にならないよう細心の心遣いも大切 である。引用, 逸話, 比喻, 気のきいたウィット, ユ一 モアなどで，上品な小さい笑い，眠気を吹き飛ばす大き い笑いを誘うものを，適当なところへ，適当に用意する ことによって，聞き手の疲労を和らげ，注意を集中させ ることに役立つものである。このように平素から素材を 蓄えておかねばならない。出る早々，発表の前置きに弁 解がましく笑わせる人がいるが，その効果は少なく，持 ち時間を減少させるのがオチである。

まず，原稿が仕上ったら，一語一語はっきり発音する
ところから, 何回も, 何回も繰り返し, 繰り返し, 話す 練習をすることである。これを怠ってはならない。テー プ・レコーダーに吹き込んで䅨古をする。聞きながら， 訂正を加え，より完全なものにしていく。自分だけでは なしに，他の人にも聞いてもらい，繰返し練習をするこ とである。

今回，O.H、P.を利用した発表者がいたが，スライドを 使う人はなかった。これら視聴覚用具もどんどん利用し て，直接目に訴え，演出効果を高めることにより，一層 よい結果が生まれる場合もある。これら資料は，見やす くすることが最大の条件であることは言うまでもない が，説明の仕方にも，細心の注意を払わねば効果は薄れ るであろう。

\section{おわりに}

「話すこと」をいつも苦手としている私の素人談義に 過ぎないが, 日頃より痛切に感じていることを率直に述 べ, 医学図書館員セミナ一の提唱者としての杞憂として 受けとめていただき，この拙文が，さいわいに，今後セ ミナ一の場で, また, Uろく日々の仕事の中で, 少しで も生かされれば，私の大きな喜びとするものである。

\section{参 考 文 献}

第 18 回日本医学会総会編 わかりやすい学会発表 東京 南江堂 昭 50 